\title{
RIGHT OF MUSLIM WOMEN IN THAILAND UNDER THE MUSLIM FAMILY LAW OF INHERITANCE CODE, 1941
}

\author{
Sulaiman Dorloh * \\ Ahmad Baha Hj Mokhtar **
}

\begin{abstract}
There are some criticisms made bynon-Muslim writers on the rights of Muslim women under the Muslim Family Law and Law of Inheritance Code, 1941 (MFLALIC, 1941) which is currently applicable in the Muslim majority areas of the four southern border provinces of Thailand namely, Patani, Narathiwat, Yala and Satul. To rebut the criticism, this study aims at analyzing and examining the provisions of the MFLALIC, 1941 and case law in relation to the rights of Muslim women after divorce and its procedures by referring to cases decided in the Provincial courts (PCs) and Muslim Religious Committee Councils (MRCCS) in those four provinces. Finally, the article discusses some propositions for future reform in order to make it in accordance with the Islamic law.
\end{abstract}

Keywords: Muslim Women, Thai Legislation, Provincial Courts, Muslim Religious Committee Councils.

\footnotetext{
* Senior Lecturer at the Law Department, Faculty of Shar'iah and Law, Universiti Islam Sultan Sharif Ali (UNISSA), dsulaiman@, unissa.edu.bn

** Assistant Lecturer at the Faculty of Usuluddin, Universiti Islam Sultan Sharif Ali (UNISSA).
} 


\section{INTRODUCTION}

Though there are no official figures of the number of Muslims in Thailand, estimates indicate it to be about 8 million, forming 10 percent of the 75 million (in 2012) of the population. ${ }^{1}$ The Muslims are located in the four major provinces like Patani, Narathiwat (Menara), Yala (Jala) and Satul. They are living primarily in the area near the Northern part of the Malay Peninsula. Moreover, the Muslims in those four provinces in the south are not an immigrant community, but indigenous to the area. They are categorized as Malay-Muslim communities. Being a non-Muslim country, Thailand does have law governing specifically to the needs of Muslim women.

There are several legislations that govern the rights of Muslim women in the four southern border provinces of Thailand. Those rights include the rights of married and divorced women. The legislations govern such protection are Conciliation of the Village Committee(CVC), Act of B.E. 2530(1987), Voluntary Self-Development and Protection of the Village Administration (VSPVA), Act of B.E.2522 (1979), the Act on the Application of Islamic Family Law and Law of Inheritance(AIFLA), 1945 and the Muslim Family Law and Law of Inheritance Code 1941.

\section{RIGHT OF MUSLIM WOMEN IN DIVORCE MATTERS UNDER MFLALIC, 1941}

In the southern four border provinces of Thailand, the laws relating to Muslim marriage, divorce and inheritance are governed under MFLALIC, 1941. There are several ways that wives may apply for dissolution of marriage under part $\mathrm{v}$ of the MFLALIC, 1941 that deals specifically with the dissolution of marriage. They are as follows:

Thanet Aphonrnsuvan, History and Politics of the Muslims in Thailand (Thaamasat University Press, n.d.), 5. 


\section{Right to Divorce by $T a{ }^{\prime} l \bar{q} q$}

Under the MFLALIC, the word of ta 'li $q$ can be inferred by referring to article 92(4) of the MFLALIC which provides to the effect that:

"Besides a husband being able to divorce his wife, țalāq may take effect when he has phit than bon talāa which has been given to him by his wife."

The word "phit" means to break, ${ }^{2}$ whereas the word "than bon" means a promise of good behavior. ${ }^{3}$ In this context, it is translated as an act of breaching the marriage agreement. Usually, the $t a$ ' $l i q$ expression contains vows not to beat the wife. If such vows are broken, the wife, in those four provinces has a right to choose either to apply for dissolution of marriage by court order or by Muslim Religious Committee Council Order.

A married woman will firstly make a complaint to the imam in her respective village; the im $\bar{a} m$ will receive verbal complaints from a married woman on behalf of the Muslim Religious Committee Council (MRCC) and take the married woman with two reliable witnesses to the office of the MRCC for further action. ${ }^{4}$

The committee will make the necessary investigation as to why the complaint is made and whether the parties have made necessary efforts to bring about reconciliation. In cases where the committee is satisfied with the answers given by the wife, the committee will ask the married woman to produce the original marriage certificate to make sure that the husband has read the ta 'li $q$ agreement. ${ }^{5}$ The committee thereupon will ask the married woman to fill in a ta $l i q$ complaint form ${ }^{6}$ and the witnesses must complete a witness examination form. ${ }^{7}$ The committee will thereupon examine the validity of the marriage certificate and make several inquiries

2 So Setha Putra, New Model Thai-English Dictionary (Bangkok: Thai Wattana Phanich, 1999) 269.

$3 \quad$ Ibid., 194.

4 Narathiwat Muslim Religious Committee Council, Ta 'liq Agreement Rule, No: 2 / 2524 (1981).

5 Borang Pengaduan Ta 'lī $q$ (Ta 'lī $q$ Complaint Form).

6 Ibid.

7 Borang Periksa Saksi (Witness Examination Form). 
as to why the complaint is lodged, and whether the parties have gone through reconciliation before the imām or any other Muslim religious institutions in the province.

In most cases, the committee receives the complaint from the wife that she is reluctant to live with her husband. If the committee is satisfied with the answers given by the wife to their queries, the committee will accept the complaint and will explain the procedures that are necessary for divorce by țala $q .{ }^{8}$

The committee will serve notice on the husband by informing the husband that on a certain date his wife has made a complaint to the MRCC that he has deserted her for more than four months, and he is required to make a counter claim in person at the office of the MRCC.

In the event that the husband fails to appear before the MRCC, the committee will presume that the husband has already agreed with the wife's complaint. The committee then will fix the date for the hearing, and the wife must be present before the committee with two reliable witnesses who know the circumstances of the case and the committee will ask the wife to recite a sworn statement. ${ }^{9}$ After the sworn statement has been recorded, the committee will issue the $t^{\prime}$ ' $\bar{l} q$ divorce certificate to the wife. ${ }^{10}$ However, if the married woman is not satisfied with the decisions of the committee, she may file a suit at the provincial courts. ${ }^{11}$

8 Haji Abdul Hamid Bin Haji Saleh, A former Vice-President of the Narathiwat Muslim Religious Council, acting Head of Ta'li $q$ Complaint Committee for the Narathiwat Religious Council, Interviewed by author, $28^{\text {th }}$ August, 2001.

$9 \quad$ Ibid.

10 In this certificate, the committee will confirm that the divorce has been effected based on the complaint received based on lafz ta'liq accompanied by two trustworthy witnesses, and stating the iddah commencement date. See Surat Keterangan Terjatuh talaq dengan ta'liq daripada suami, issued by Yala Muslim Religious Committee Council, No: 0700.

11 Decided cases of Mdm Rungrat Yong Setar V Suaphol Yong Setar, The Narathiwat Provincial Court, Civil Suit No: 46 / B.E. 2544 (2001); Latipah Malee v Yusoh Malee, Patani Provincial Court, Civil Suit No : 571 / B.E. 2542 (1999). 
In the case of Nuriyah $v$ Ma'ri Peng Che Leh, ${ }^{12}$ in which the wife, Nuriyah, had applied to the Patani Provincial Court to confirm a divorce by $t a$ ' $l \bar{q} q$ under article 92 (4) of the MFLALIC. She claimed that the husband had pronounced the conditional divorce or $t a$ ' $l \bar{l} q$ and he had failed to comply with it by willfully deserted her for a period of six months. Moreover, he had not given any maintenance to his wife or his children.

The learned Dato' Yuthitham (Muslim judge) of the Patani Provincial Court, Dato' Apirat Mad Said held that the wife was entitled to maintenance, and since the husband had failed to give sufficient maintenance to his wife for more than four months, she was also entitled to obtain divorce in accordance with the ta 'i $q$ agreement which had been made before the imäm. The court then ruled in her favour.

In the case of Hama $v$ Pisoh Molo, ${ }^{13}$ the respondent alleged that her husband had deserted her and her children for over one year. The learned Dato' Yuthitham ordered the marriage to be dissolved. In the Narathiwat Provincial Court case of Siri Nipha Che Senik $v$ Isma-ae Muda, ${ }^{14}$ the learned Dato' Yuththam was of the view that since the husband has deserted his wife for over one year and had failed to provide maintenance for her and her children as an ordinary spouse, the court had a strong reason to terminate the marriage. Therefore, it shows that, in the view of the learned Dato' Yuthitham in the above-mentioned cases, a wife has to show to the court that she has willfully been deserted by her husband and as long as grounds for divorce are recognized by the which the provincial courts will grant the divorce to the wife.

The above-mentioned judgments were justified by the Narathiwat Provincial Court case of Mdm Rungrat Yong Setar v Suaphol Yong Setar, ${ }^{15}$ the wife brought an application to confirm the $t a$ ' $l i q$ agreement as the husband had deserted her more for than six months. The Narathiwat Muslim Religious Committee Council (NMRCC) made a decision in favour of the applicant. The applicant then applied to the Narathiwat Provincial Court

\footnotetext{
12 Patani Provincial Court, Civil Suit No: 787 / B.E. 2542 (1999).

13 Patani Provincial Court, Civil Suit No: 761 / B.E. 2542 (1999).

14 Narathiwat Provincial Court, Civil Suit No: 14 / B.E. 2544 (2001).

15 Narathiwat Provincial Court, Civil Suit No: 46 / B.E. 2544 (2001).
} 
(NPC) for the confirmation of divorce by ta ' $\bar{l} q$ as her husband had assaulted her physically and did not provide maintenance to her and her three children for more than one year.

The learned Dato'Yuthitham of the Narathiwat Provincial Court (NPC), Dato' Abdullah Tuan Meden, held that since the parties were both Muslims living in the southern four border provinces of Thailand and were married according to Islamic law and registered their marriage at the Narathiwat District Officer Office (NDOO), the court in this case confirmed divorce by ta 'li $q$ as requested by the applicant. In these two cases, it is observed that the Patani Provincial Court (PPC) applied the provisions of the MFLALIC whereas the Narathiwat Provincial Court (NPC), Dato' Yuthitham did not apply the provisions of the MFLALIC.

In some cases the Dato' Yuthitham applies the Thai Civil and Commercial Law Code 1934, book V to dissolve a marriage by talāq. However, according to this law, a wife must prove to the court that she has been deserted by her husband continuously for one year or more ${ }^{16}$ whereas under the MFLALIC it depends on ta 'li $q$ pronouncement-lafz al-ta 'li $q$ normally after four months the court may order the marriage to be dissolved by ta 'li $q$.

In the case of Mariyea Tayi'@ Maneav Hama Tayi', ${ }^{17}$ a wife requested her marriage to be dissolved based on lafz al-ta 'li $q$ which was attached to the marriage certificate (No: 20/2543). The Yala Muslim Religious Committee Council (YMRCC) had confirmed the applicant's claim and granted the divorce to the applicant. The applicant later filed a suit at the Yala Provincial Court by alleging that her husband had deserted her and her children for over two years. The learned Dato' Yuthitham had granted the dissolution of the marriage by referring to article 1516 (5) of Thai Civil and Commercial Law Code 1934, book v. However, this approach is contrary to the article 92 (4) of the MFLALIC and article 3 of the act of the application of Islamic law in Patani, Narathiwat, Yala, and Satul, B.E. 2489 (1946).

16 Thai Civil and Commercial Law Code 1934, book V, article 1516 (5).

17 Yala Provincial Court, Civil Suit No: 215 / B.E. 2544 (2001). 


\section{Right of Dissolution of Marriage by Way of Faskh}

The MFLALIC recognizes dissolution of marriage by fask $h$ which can be instituted by both parties, husband and wife. Article 110 of the MFLALIC defines the dissolution of marriage by pasakh ${ }^{18}$ as follows:

"A rescission of the marriage contract whereby a husband or wife must institute their cases to the court to dissolve a marriage contract by phiti ${ }^{19}$ pasakh."

The grounds for dissolution of marriage by faskh which are stated in article 111 of MFLALIC are applicable to all defects and diseases, including insanity, ${ }^{20}$ vitiligo, ${ }^{21}$ leprosy of either spouse, ${ }^{22}$ abnormal size, ${ }^{23}$ impotency ${ }^{24}$ and amputation of the husband's genita ${ }^{25}$ and vaginal defects of the wife, for example, ratq $^{26}$ and qarn $^{27}$ of the wife. ${ }^{28}$ In other words, the MFLALIC makes no distinction between impotency of the husband and any other kind of defects or diseases as mentioned in Article 111 of the MFLALIC.

In the case of Kholeeyoh Abu Dayo v Mahama Abu Dayo. ${ }^{29}$ In this case, the applicant filed a suit at the Yala Provincial Court (YPC) alleging that her husband had been suffering from impotency for the last four years. The court asked the applicant to get a letter of confirmation from the Yala Muslim Religious Committee

18 The MFLALIC adopts the Malay Muslim pronunciation. The correct spelling is "faskh."

19 It is a Thai word which means a ceremony. Thus, the phrase "Phiti pasakh" means faskh's ceremony.

20 MFLALIC, article 111(1).

21 Ibid.

22 Ibid.

23 MFLALIC, article 111(2).

24 MFLALIC, article111 (3)(a).

25 MFLALIC, article 111(3) (b).

26 A muscular growth which is sometimes found covering the vulva and the womb.

27 A hard small bone which is growing likes a horn in the woman's vagina.

28 MFLALIC, article 111(4).

29 Yala Provincial Court, Civil Suit No: 3 / 2543 (2000). 
Council (YMRCC). After the applicant furnished the letter, the court ordered the marriage to be dissolved by fask $h$ without giving a chance to the husband to disprove her allegation.

\section{Right of Dissolution of Marriage by way of Dhara Syar'ie (Cruelty)}

In the case of Masare Wae Mada V Prasit Wae Mada. ${ }^{30}$ The applicant in this case filed a suit at the Patani Provincial Court (PPC) by alleging that her husband had assaulted her physically. The learned Dato' Yuthitham was of the view that if the court was satisfied that the husband had assaulted the wife's physically, the court might dissolve the marriage by faskh.

This judgment is upheld by the Narathiwat Provincial Court (NPC) of NisohHami@Su-Deng@SenikvDoloh Senik@Bin Arwea. ${ }^{31}$ The husband in this case had hurt the wife by slapping his wife's face until it bled, after which he left the home. The wife later instituted a claim at the Narathiwat Muslim Religious Committee Council (NMRC) as well as at the Narathiwat Provincial Court (NPC). The learned Dato' Yuthitham, Dato' Ni Wae Ali Ni Loh, dissolved the marriage by faskh.

From the two decided cases, it can be concluded that the provincial courts seem to agree to order the marriage to be dissolved on the grounds of cruelty when the court is satisfied that there is cruelty on the part of the wife. This is despite the fact that there is no express provision about cruelty in the MFLALIC, 1941. Therefore, it is recommended that the MFLALIC cruelty should be included as a ground for faskh in order to be in line with the judgment of the Dato' Yuthitham as well as with the provisions of laws in other countries as discussed above.

\section{Right to Maintenance during Marriage}

The MFLALIC, 1941 clearly states the husband's liability to maintain his wife. Article 63 of the MFLALIC, 1941 provides, inter alia, that it is the duty of a husband to maintain his wife by providing her with accommodation, clothing, and food as is

\footnotetext{
$30 \quad$ Patani Provincial Court, Civil Suit No: 390 / B.E. 2534 (1997).

31 Narathiwat Provincial Court, Civil Suit No: 427 / B.E. 2543 (2000).
} 
reasonable having regard to his means. This law provides that the obligation of the husband to maintain his wife is absolute.

Article 63 (1) of the MFLALIC, 1941 has listed a wife's maintenance to include all those things which are necessary for the wife's daily life such as food, clothes and lodging. With regard to food, it should be paid in consonance with the social status of the husband.

It was justified in the case of Raja Najmin Bin Raja Mahmud $v$ Nor Hasmani, ${ }^{32}$ in which the applicant, Raja Najmin Bin Raja Mahmud, a Malaysian citizen, born in Kelantan, Pasir Putih. She requested the Narathiwat Muslim Religious Committee Council (NMRCC) to dissolve her marriage by faskh on the ground that her husband was unable to pay her maintenance for a period of three months and twenty-four days. The applicant gave a sworn statement to the Narathiwat Muslim Religious Committee Council (NMRCC) that she was always obedient to her husband. He also failed to pay a deferred dowry which amounted to RM 300. Two witnesses were called, they were Raja Mahmud Bin Raja Mamat and Haji Abu Bakar Bin Che Loh. After the committee was satisfied with the witnesses, the committee asked the applicant to pronounce lafz faskh. In Piah Binti Abdul Rauf v Syed Abdullah Bin Syed Ahmad, ${ }^{33}$ the committee of the Narathiwat Muslim Religious Council (NMRC) ordered divorce by ta 'li $q$ since the husband had not given her maintenance contrary to the terms of the talāq pronounced by him. From the above cases, it can be seen that the grounds or basis for divorce by $t a$ ' $l i q$ in those four provinces are based on the failure to give maintenance.

\section{Right to Divorce by Tebus Talaq}

Under the MFLALIC, 1941, a Muslim woman is allowed to apply for a divorce via $\mathrm{khul}^{\text {' }}$ or cerai tebus talaq if she wishes to dissolve he marriage when her husband refuses to pronounce a țalāq.

32 Narathiwat Muslim Religious Committee Council (No citation).

33 Narathiwat Muslim Religious Committee Council, Ta'liq Case No: 40 / B.E. 2530 (1989). 
In the case of Kiah Ahmad v Mat Jusoh Abd. Mutalib. ${ }^{34}$ In this case, the applicant had requested the Narathiwat Muslim Religious Committee Council (NMRCC) to dissolve her marriage by khul 'on the ground that her husband always beat her when she went to her relatives' house. He also failed to provide sufficient maintenance for her. The husband refused to pronounce țalāq. The applicant, therefore, requested the husband to dissolve the marriage by $\mathrm{khul}$ " at the amount of 5,000 Baht cash. The husband still refused. The Narathiwat Muslim Religious Committee Council (NMRCC) brought the case to the conciliatory committee. The conciliatory committee, after examining the amount of mahr totaling 15,300 baht ordered the applicant to pay 5,000, Baht in favour of the husband and asked the husband to pronounce țalāq.

This can be illustrated in the case of Kiah Ahmad v Mat Jusoh Abd. Mutalib. ${ }^{35}$ The applicant in this case had requested the Narathiwat Muslim Religious Committee Council to dissolve her marriage on the grounds that her husband had always beaten her when she went to her relative's house and he also failed to provide sufficient maintenance for her. The husband refused to pronounce tala $q$. The applicant, therefore, requested the husband to dissolve the marriage by khul ' at the amount of 5,000 baht cash. The husband still refused. The conciliatory committee, after examining the amount of mahr totaling 10,000 baht, ordered the applicant to pay 5,000 baht in favour of the husband. The husband agreed and the marriage was dissolved by khul ' as requested by the applicant.

\section{THE PROCEDURE OF T⿱ALLA $Q$}

Generally, dissolution of marriage by talāq in Thailand can be done either before the imām in the respective village or at the office of the Muslim Religious Committee Council in certain

34 Kiah Ahmad v Mat Jusoh Bin Abd Mutalib, Khul' case (no citation) Narathiwat Muslim Religious Committee Council.

35 Kiah Ahmad v Mat Jusoh Bin Abd Mutalib, Khul' case (no citation) Narathiwat Muslim Religious Committee Council. 
provinces of Thailand. ${ }^{36}$ After talāq has been granted, the imām or the committee of the MRCC will then issue a certificate of divorce to both parties. ${ }^{37}$ An imām or the committee of the Muslim Religious Committee Council shall make three copies of the proof of divorce. First copy shall be given to the former husband; second copy shall be given to the former wife and the third copy shall be kept by the imām or the committee of the MRCC for his file..$^{38}$ This certificate is considered as a religious document that has no legal validity compared to other Thai government documents unless it is confirmed by the provincial courts..$^{39}$ As a result, some of the divorced couples tend to file legal suits once again at the provincial courts in order to confirm the divorce that has been granted by the imām or Muslim Religious Committee Council. When the legal suits have been accepted by the provincial courts, Dato' Yuthithams will apply the provisions in the MFLALIC to confirm and declare that talaq has been legally effected according to Islamic law. Besides that, țalāq sometimes occurs at home.

The process of applying for a Muslim divorce in the southern border provinces of Thailand can be understood in the diagram I below:

36 It is unfortunate to note that the imāms and committee members of the MRCC are not acting as registrar as understood by many people and they are not considered as public servants according to the Thai Penal Code. Because by virtue of the Administration of Islamic Organization Act of 1997 imāms and committees of the MRCC have the authority to issue the certificate of marriage and divorce but not to register it. Thus, in conducting their duties they will not be responsible for any consequences.

37 Surat Keterangan Cerai (The Certificate of Divorce)

38 Haji Abdul Samad Dosamad, a conciliatory committee at Narathiwat Muslim Religious Committee Council, Narathiwat, Interview by the author, 28th August, 2001.

39 Muhammadzakee Cheha. Islamic Family Law in Thailand, Paper presented at International Family Law Conference, Family Law in the 21 $1^{\text {st }}$ Century: Challenges and the Way Forward: Crown Princess Hotel, Malaysia,16-17 January,2007, at 94 


\section{Diagram I}

\section{The Process of Applying for a Muslim Divorce in the Southern Four Border Provinces of Thailand}

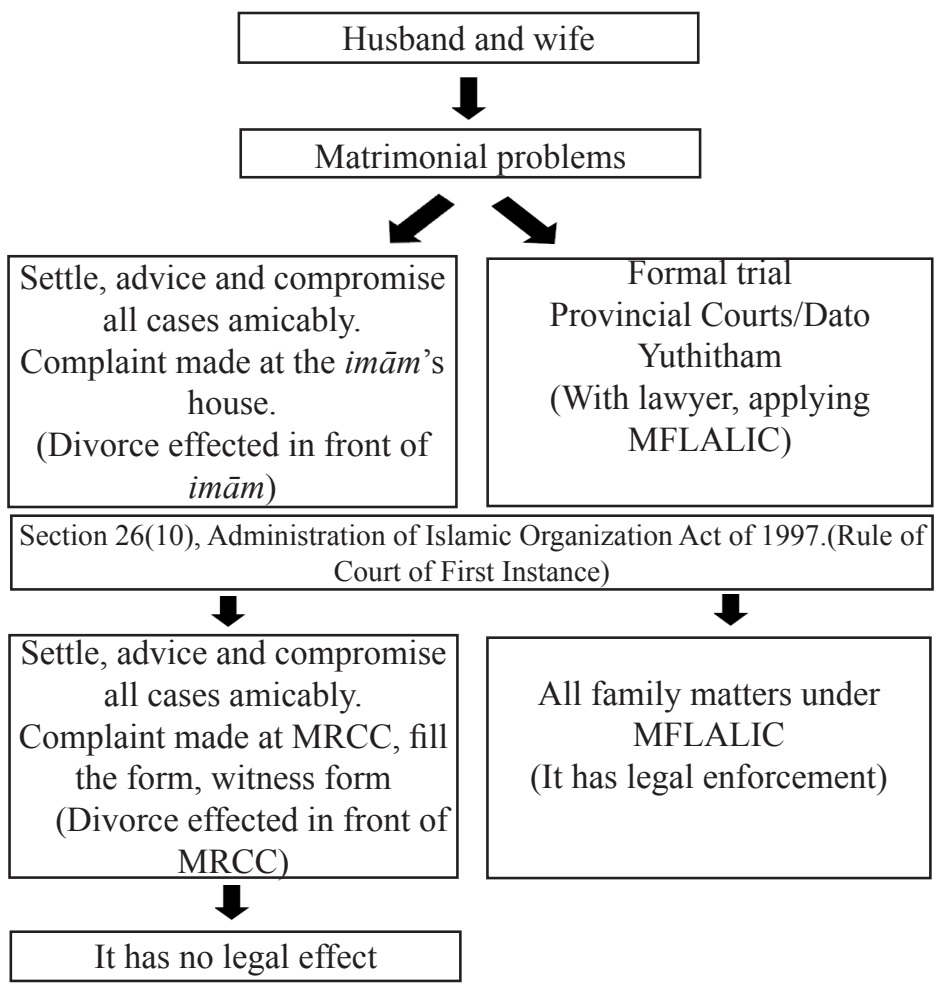

As soon as a divorce application is submitted to the provincial courts, the court registrar at the provincial courts will check the documents. After completed documents have been submitted and registered, the court will decide on the date of the trial and issue summons. The process in the provincial courts in the southern border provinces of Thailand can be seen in diagram II below: 


\section{Diagram II}

\section{Divorce Application Process at the Provincial Courts}

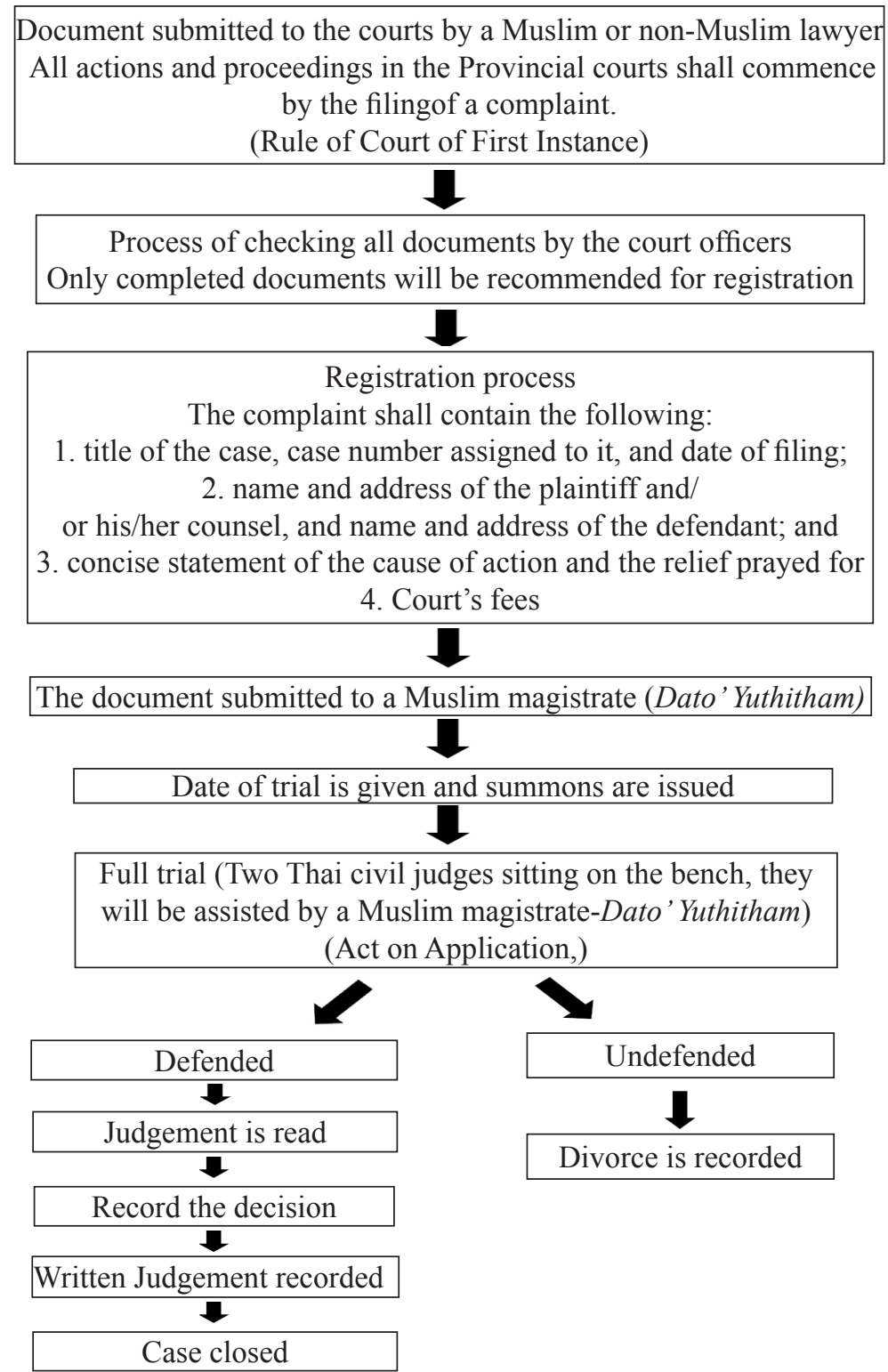


A decision of the provincial court is final. However, appeal can be made to court of appeal at the regional court, which is situated at the Sonkhla province. The appeal can be made on the question of facts but not on question of laws. There are no provisions provided under the MFLALIC, 1941 either for the registration of talāq or regarding the procedures of such divorce. A wife may not even know she has been divorced until she is informed by another party. In a case study conducted in Thailand, it has been found that every application for divorce that was filed in the provincial courts in these four provinces was filled by a wife, because husbands can simply pronounce talāq without having to petition the court for divorce. And for the purpose of registration, the Thai Civil and Commercial Law Code 1934, book V will be applied irrespective of whether they are Muslims or Buddhists. ${ }^{40}$ This is because of unavailability of the registry office for Muslim Marriage and Divorce. The usual practice is that the application for divorce and married must be made at the office of the district officer.

In the case of Muslim applicants, all applications for talāq must be first presented to the local imām in his or her residence. ${ }^{41}$ After the imām has received the application, the applicant must fill in the divorce application form at the Muslim Religious Committee Council. ${ }^{42}$ The committee will then ask the couple to come before the committee accompanied by the imām. The committee will endeavour to effect reconciliation. If the committee is satisfied that the marriage has irretrievably broken-down, the committee will ask the husband to pronounce taläq. ${ }^{43}$ The committee will

40 Thai Civil and Commercial Law Code 1934, book V. Article 1514 of the code 1934, book V provides inter alia that divorce may be affected only by mutual consent or by judgment of the court.

41 Section 26(10), Administration of Islamic Organization Act of 1997. It provides that the Provincial Commission is only to issue the letter of recommendation on Muslim marriage and divorce but not to register marriage and divorce.

42 Application form for divorce (A 1 for male \& A 2 for female) issued by Narathiwat Muslim Religious Committee Council.

43 Haji Abdul Samad Dosamad, a conciliatory committee member at Narathiwat Muslim Religious Committee Council, Narathiwat, Interview by the author, 28th August, 2001. 
issue a certificate of divorce ${ }^{44}$ by recording the nature of the pronouncement of talāq. A certified copy will be kept at the Muslim Religious Committee Council for reference. If the husband refuses to pronounce tala $q$, the committee will ask the husband to pronounce a divorce by redemption after the amount of the payment is agreed upon by the parties..$^{45}$ In other words, not every talāq cases can be granted directly by Imam or the committee. Islam encourages the spouses to reconcile when they find that the marriage can be saved.

As has been mentioned earlier, in those four provinces, țalāq may take place either before imāms or the Muslim Religious Committee Council or before the Dato' Yuthithams in the provincial courts. The reason is that Dato' Yuthitham is appointed by the government to settle marital disputes for Muslims in those four provinces only, viz. Narathiwat, Yala, Patani and Satul provinces. On the other hand, in practice it is observed that there are some the Dato' Yuthitham who were appointed by the Muslim Religious Committee Council to become a committee member of the Muslim Religious Committee Council. In such a case, marriage and divorce may take place before him as a committee member but not as a judge. ${ }^{46}$

\section{CONCLUSION AND RECOMMENDATIONS}

The MFLALIC, 1941 clearly protects the Muslim women right according to Islamic law. Though, the code has not been brought to parliament for approval. By virtue of the Act on the Application of Islamic Family Law and Law of Inheritance, 1945, the code, 1941 is frequently used as a reference by the Dato' Yuthithams as well as the Thai civil judges in the Provincial Courts of Patani, Narathiwat, Yala and Satun in resolving disputes matrimonial disputes among the Muslims in the Deep south.

The provisions mentioned above provide rights for Muslim women to have a divorce or judicial divorce from the provincial

\footnotetext{
44 See Divorce Certificate.

45 Ibid.

46 For example Dato' Abdullah Tuan Meden, a retired Dato' Yuthitham of Narathiwat Provincial Court.
} 
courts and to make a claim on their respective rights in terms of matrimonial property, areas of maintenance, jointly acquired property and custody of children in the four provinces only whereas the Muslims women who are living outside those provinces are deprived of their rights. Therefore, the application of Islamic family and law of inheritance must be extended to whole country. Secondly, being a piece of Islamic law in Thailand, Thai government recognizes Islamic family law and law of inheritance based upon Islamic law principle. The government must pay more attention towards the implementation and revision the contents of Islamic law. The efforts for reforming the contents of the code should be given priority before its application. The suggestions that have been highlighted in this paper may offer some rooms for future amendments and improvements toward the implementation of Islamic law in Thailand.

\section{REFERENCE}

Khatchat Phai Burut Phat. Thai Muslim. Bangkok: Winyuchun, n.d.

M.B, Hooker. Islamic Law in South East Asia. New York: Oxford University Press, 1984.

Muhammadzakee Cheha. "Islamic Family in Thailand." Paper presented at International Family Law Conference, Family Law in the 21 $1^{\text {st }}$ Century: Challenges and the Way Forward, on 16-17 January, 2007, Crown Princess Hotel, Kuala Lumpur, Malaysia.

Rongruj Reung Watwong. Krub Khrua (Family). Bangkok: Winyuchun, n.d.

Seni Mudmarn. Social Science Research in Thailand: The Case of the Muslim Minority." In Omar Farouk Bajunid (eds). Muslim Social Science in ASEAN. Kuala Lumpur: Yayasan Penataran Ilmu, 1994.

So Setha Putra. New Model Thai-English Dictionary. Bangkok: Thai Wattana Phanich, 1999.

Sulaiman Dorloh. "Dissolution of Marriage and Divorce Proceedings at Majlis Ugama Islam and Provincial Courts in Southern Four Border Provinces of Thailand." Paper 
presented at the International Family Law Conference, Family Law in the 21 ${ }^{\text {st }}$ Century: Challenges and the Way Forward, on 16-17 January, 2007, Crown Princes Hotel, Kuala Lumpur, Malaysia.

Sulaiman Dorloh. "The Code of Muslim Family Law and Law of Inheritance (1941) as Applicable in the Provincial Courts of Southern Four Border Provinces of Thailand: Issues and Prospects." Paper presented at the International Seminar, Isu-isu Kontemporari dalam Syariah dan Undang-undang, on 17-18 May, 2011, Dewan Persidangan Utama, Pusat Persidangan Antarabangsa, Negara Brunei Darussalam.

Sulaiman Dorloh. "The Position of Islamic Law in the Four Southern Border Provinces of Thailand." Jurnal Syariah 14, Jul-Dec (2006), 6-7.

Thanet Aphonrnsuvan. History and Politics of the Muslims in Thailand. Thamasat University, n.d.

W. Jones, Garvin. Marraiage and Divorce in Islamic South-East Asia: Thai Social, Economic and Legal Context. New York: Oxford University Press, 1944.

\section{Statutes/Legislations/Acts}

Act on the Application of Islamic Family Law and Law of Inheritance, 1945.

Constitution of the Kingdom of Thailand, 1997.

Islamic Organization Act B Administration of the Court of Justice in the matter of Conciliation of the Disputes B.E. 2544(2001). Thai Civil and Commercial Law Code 1934.

Mosque Act, 1947.

Mosque Act, 1955.

Patronage of Islam Act, 1945.

Practice suggestions issued by the President of the Supreme Court on 7 March B.E.2539 (1996).

Regulations for the Registration of Mosque Act, 1948.

Thai Civil Procedure Amendment Act (No: 17) B.E.2542 (1999).

The Arbitration Act B.E. 2530 (1987). 
The Royal Act concerning the Administration of Islamic Organization B.E.2540 (1997).

\section{Cases Referred}

Hama V Pisoh Molo, Patani Provincial Court (PPC), Civil Suit No: 761 / B.E. 2542 (1999).

Kholeeyoh Abu Dayo V Mahama Abu Dayo, Yala Provincial Court (YPC), Civil Suit No: 3 / 2543 (2000).

Kiah Ahmad V Mat Jusoh Abd. Mutalib, Narathiwat Muslim Religious Committee Council (NMRC), (no citation).

Mariyea Tayi’@Manea V Hama Tayi', Yala Provincial Court (YPC), Civil Suit No: 215 / B.E. 2544 (2001).

Masare Wae Mada V Prasit Wae Mada, Patani Provincial Court (PPC), Civil Suit No: 390 / B.E. 2534 (1997).

Mdm Rungrat Yong Setar V Suaphol Yong Setar, Narathiwat Provincial Court (NPC), Civil Suit No: 46 / B.E. 25443 (2001).

Nisoh Hami@Su-Deng@Senik V Doloh Senik@ Bin Arwea, Narathiwat Provincial Court (NPC), Civil Suit No: 427 / B.E. 2543 (2000).

Nuriyah V Ma'ri Peng Che Leh, Patani Provincial Court (PPC), Civil Suit No: 787 / B.E. 2542 (1999).

Piah Binti Abdul Rauf V Syed Abdullah Bin Syed Ahmad, Narathiwat Muslim Religious Committee Council (NMRC), Ta,liq case no: 40/B.E.2530(1989).

Raja Najmin Bin Raja Mahmud V Nor Hasmani, Narathiwat Muslim Religious Committee Council (NMRC), (no citation).

Siri Nipha Che Senik V Isma-ae Muda, Narathiwat Provincial Court (NPC), Civil Suit No: 14 / B.E. 2544 (2001). 